\title{
Innovation Culture, R\&D Intensity, and Firm Innovation
}

\author{
Shan Liu \\ Xi'an Jiaotong University \\ shan.1.china@gmail.com
}

\author{
Muyu Zhang \\ Xi'an Jiaotong University \\ muyu.zhang.china@gmail.com
}

\author{
Baojun Gao \\ Wuhan University \\ gaobj@whu.edu.cn
}

\begin{abstract}
This paper aims to investigate the value of two types of innovation culture, namely employeeperceived and firm-proclaimed innovation culture. We quantify how employees perceive innovation culture by analyzing the text of 191542 employee reviews on Glassdoor and identifying the presence of firm-proclaimed innovation culture from their official websites. The results indicate that employeeperceived innovation culture has a positive influence on innovation output whereas firm-proclaimed innovation culture does not. Moreover, $R \& D$ intensity negatively moderates the effect of employee perceived innovation culture on firm innovation, such that the effect of employee perceived innovation culture is lower when R\&D intensity is higher. This finding contradicts the observation of previous studies that used cross-sectional survey data. Nevertheless, our finding is consistent with the view that innovation culture cultivates the intrinsic motivation of employees, but the symbiotic control that comprises the increase of $R \& D$ intensity weakens it.
\end{abstract}

\section{Introduction}

Innovation is crucial to the survival and development of firms. It creates new products as well as new services that enable firms to obtain competitive advantages and achieve considerable market returns [1]. Given the significance of innovation, firms expect to understand the elements that determine incentives to innovate, especially for public firms because of their more complex internal and external environment [2,3]. Compared with a private firm, "myopic stock market incentives" propel managers to cut $R \& D$ expenditures and prefer projects with short-term and less risky returns that are favored easily by shareholders and potential investors $[4,5]$. Thus, when improvements in R\&D expenditure encounter various restrictions, public firms transfer the perspective from tangible to intangible focus and discover that innovation culture may be a new avenue for improving innovation output [6]. The culture-centric theory of innovation posits that in the era of homogenization, innovationsupportive culture may be the most important driver of the innovation process [7].

In order to support innovation through culture, top managers represented by the CEO can define it and proclaimed through official channels (e.g., firm's homepage) [8]. Interestingly, 80 percent of S\&P 500 firms advise that innovation is the key element of their culture, but the reality is, they exhibit large diversity in innovation when eliminate the differences of industry and firm size [9]. By contrast, the firms with employees widely perceived innovation culture and thus highlight self-learning and risk taking always perform well in innovation [10]. These facts may indicate that the innovation culture proclaimed by top managers or widely shared by most employees may create diverse influences on firm innovation. Our study tries to unpack this phenomenon through identifying the value of two types of innovation culture. We define the innovation culture conveyed through official channels and shared by top managers as firm-proclaimed innovation culture. Similarly, the innovation culture shared by most employees who come from different hierarchies and different positions is treated as employee-perceived innovation culture. Moreover, investigating their effects on firm innovation may also be conducive to explain the contradictory findings in pervious literatures that discuss the importance of innovation culture [11-14].

In addition to the influence of intangible resources (e.g. innovation culture), innovation is also a process highly relies on the input of tangible resources (e.g., R\&D intensity, measured by R\&D expenditure divided by sale) $[15,16]$. Increasingly, researchers turned interests to their joint effect on firm innovation but obtained opposite findings. For instance, several studies have found that tangible resources (e.g., financial incentives) diminish the intrinsic motivation of employees and weaken the effects of intangible resources (e.g., transformational leadership), which suggests a substitute effect [15, 
17]. Nevertheless, others identify a complementary effect between them [16]. In our research context, as one of the main intangible resources, the effects of innovation culture may be changed by the input of tangible resources (e.g., R\&D intensity measured by R\&D expenditure divided by sales). For better use of this "spiritual weapon" (i.e., innovation culture), we try to investigate their joint effects on firm innovation.

Taken together, this study aims to answer the following questions:

(1) How do the two dimensions of innovation culture (firm-proclaimed and employee-perceived innovation culture) influence public firm innovation?

(2) How does R\&D intensity change the relationship of innovation culture with firm innovation?

To answer these questions, we use a combined method of deep learning and text mining to quantify employee perceived innovation culture by analyzing the text of 191542 employee reviews on Glassdoor (a leading career community in America) and identifying the presence of firm-proclaimed innovation culture from their websites. Notably, this method overcomes the empirical limitations of using cross-sectional survey data or traditional text mining $[18,19]$. Second, we collect patent data from the United States Patent and Trademark Office (USPTO) and supplementary financial data from Compustat. We then develop an empirical model to test our hypotheses. Our economic specification model examines the firm innovation measured by patent number as a function of innovation culture by controlling for R\&D intensity, financial leverage, prior performance, employee satisfaction, firm size, firm age, other dimensions of corporate culture, and industry, region, and year fixed effects. Finally, we perform robustness checks to validate our results.

\section{Literature review}

Innovation determines the fate of a firm. It is both a process and an outcome that involves "generating, adopting, implementing and incorporating new ideas, new practices, and new artefacts" [20,21]. A key topic in innovation-related research is to examine what factors trigger the firm's innovation ability [6, 22-24]. Based on the resource-based view [25, 26], at least two research streams examine this topic. One stream highlights the importance of tangible resources and focuses on $R \& D$ expenditure, financial incentives, and policy support [27-29]. The other stream emphasizes the significance of intangible resources and firms are advised to build an innovation-supportive culture or construct a work climate of innovation to attain sustainable innovation capability $[24,30,31]$. In line with our research questions, we first introduce the previous research that involves the relationship between innovation culture and firm innovation. We then review the interaction between the main spiritual resource (e.g., innovation culture) and the main tangible resource (e.g., R\&D intensity) within the innovation process.

\subsection{Innovation culture and firm innovation}

Although definitions vary, organizational culture is conceptualized widely as a shared set of beliefs, values, assumptions, and norms embedded within organizational missions and practices [32]. The dimension of organizational culture that emphasizes creativity, experimentation, adaptability, and risktaking is often referred to as innovation-supportive culture [16], innovation culture [24], or innovationoriented culture [11]. The relationship between innovation culture and firm innovation has been examined widely and has yielded contradictory findings. For instance, derived from resource-based view, Brettel and Cleven treat innovation culture as a strategic resource that has a positive effect on a firm's openness to external knowledge and further increase the performance of new product development [30]. Berson also posits that innovation culture is related positively to product innovation and further promotes sales growth because organizations that emphasize risk-taking and interest-seeking encourage the utilization of growth opportunities even in the face of intermittent setbacks [33]. These findings are accordance with the common understanding that high innovation culture can improve firm innovation and emphasize the importance of the essence of innovation culture (i.e., risk-taking, experimentation, and adaptability) in knowledge absorption, resource use, and idea creation. Nevertheless, several researchers found that the relationship between innovation culture and firm innovation is insignificant and even has a negative correlation [12, 23]. Thus, researchers represented by Khazanchi, Lewis, and Boyer have attempted to reveal the internal mechanism of this phenomenon. They decompose innovation culture into two basic value profiles, flexibility values (stressing empowerment, change, and creativity) and control values (encouraging stability, productivity, and efficiency) and found that only flexibility value has a positive effect on innovation performance. The effect of the control value is not significant. Thus, within a firm, if the profile of control value is dominated by the innovation culture, the whole effect on firm innovation may insignificant or negative. 
Benefitting from the efforts of previous researchers, the relationship between innovation culture and firm innovation appears to be obvious; however, these works present at least three research gaps. First, the respondents of almost all of these studies are CEOs [11, 23], managers [6, 13, 14], or employees working in several departments [34]. Innovation is a kind of behavior that requires topdown cooperation among different departments of the whole company [35]. However, these studies only investigated the innovation culture shared in limited firm groups and not those shared by employees from different hierarchies and different positions. Second, these studies are based on cross-sectional survey data that involve few employees per firm and focus mostly on a single industry. The design and data also limit the generalizability of their findings. Third, existing research presents contradictory findings on the relationship between innovation culture and firm innovation. Terziovski used survey data collected from CEOs of firms and found an insignificant effect. We may speculate that the innovation culture proclaimed only by CEOs may not have a positive effect on firm innovation. Furthermore, the innovation culture shared by different groups may generate diverse effects.

Therefore, in this study, we introduce firmproclaimed and employee-perceived innovation culture. Analyzing the effects caused by them may explain in part the contradictory findings mentioned above from the perspective of culture coverage. We also measure innovation culture by using a combined method of text mining and deep learning to fill the measuring gaps in past research.

\subsection{Interaction of tangible resources and intangible resources in firm innovation}

On the basis of the resource-based view, previous studies have extensively explored the direct effects caused by tangible resources (e.g., R\&D Intensity) and intangible resources (e.g., innovation culture) in the firm innovation process. However, the resource orchestration theory argues that the combination of different resources appears to be more important and managers need to orchestrate them to realize organizational objectives $[36,37]$. Thus, many researchers have focused on the interaction effects of various resources and introduce three interaction modes as follows: tangible-tangible (e.g., the interaction between $R \& D$ subsidies provided by government and $\mathrm{R} \& \mathrm{D}$ expenditure financed by companies) [27], intangible-intangible (e.g., the fit of innovation culture and CEO leadership) [38], and tangible-intangible. In line with our research questions, we focus mainly on the last pattern.

Two streams of research related to this topic found opposite findings. For instance, Chen et al. found that financial incentives negatively moderates the positive effect of transformational leadership on technological innovation [17]. In this way, when the level of financial incentives is high, the influence of transformational leadership on technological innovation will be neutralized. The principle stems from the cognitive evaluation theory, which argues that external factors (e.g., tangible rewards, standards, rules, deadlines, and appraisal) are inclined to undermine the intrinsic motivation of employees [15]. This finding may conform to the understanding that the power of intangible resources is higher when tangible resources are at a lower level. Nevertheless, in the innovation process, some studies have suggested that the relationship between intangible and tangible resources is not substitutional but rather complementary [16, 39-41]. Among the findings of previous research, the most relevant to the current study is the identification of the interaction effect of innovation-oriented culture and R\&D spending to be significantly positive [16]. This finding in line with the view that innovation culture likely encourages the use of R\&D spending to explore and develop novel and risky ideas. Notably, this result was obtained by using cross-sectional survey data and with responders from a limited group. In addition, a big difference can be observed between $R \& D$ spending and $R \& D$ intensity. Numerous studies treat $R \& D$ spending divided by total sales or assets as the proxy for $R \& D$ intensity that reflects the relative emphasis on firm innovation from the perspective of economic input $[42,43]$. However, R\&D spending is an absolute value that cannot express well the pressure brought about by $\mathrm{R} \& \mathrm{D}$ investment. The pressure derived from top managers may have a significant influence on the innovation behavior of employees (e.g., for two firms whose economic foundation varies hugely but has the same input for $R \& D$ spending, the firm with lower assets may pay more attention to innovation output and thus bring pressure to employees)

Considering the mixed interaction effect between intangible and tangible resources within innovation process and the design limitations contained in previous literature, our study focuses on the interaction of main intangible resource (i.e., innovation culture) and main tangible resource (i.e., $R \& D$ intensity) in innovation process and determines when innovation culture will play a more significant role. 


\section{Research model and hypotheses}

We developed the research model based on our research questions and combined with resource-based view and resource orchestration theory as shown in Figure 1.

\subsection{Effects of innovation culture}

Considering the difference between conveying approach and coverage, we divided innovation culture into two dimensions, i.e., firm-proclaimed and employee-perceived innovation culture. Previous studies widely agree that innovation culture as a kind of spiritual resource plays a pivotal role in the innovation process and has a positive effect on the output of innovation [7, 11, 30]. Thus, we posit that different modes of innovation culture positively affect firm innovation.

We first discuss the firm proclaimed innovation culture that refers to the innovation culture conveyed through official channels of firms and shared by top managers. It reflects the atmosphere that top managers aim to build and expect to influence the whole group of employees. Proclaimed innovation culture may affect firm innovation through two channels. First, top managers represented by the CEO are the spiritual leaders of a firm and they create a climate that encourages risk-taking and exploration [44]. The top managers who highlight innovation can serve as charismatic role models for perseverance and creativeness [45]. Through this mechanism, they can mobilize the initiative held by employees to lend spiritual power to firm innovation. More specifically, top managers express the importance of firm innovation through firm-proclaimed innovation culture, which strengthens employees' intrinsic motivation to achieve innovation, resulting in employees working harder to perform well, thereby enhancing the probability of R\&D success [46]. Second, top managers who highlight innovation may more likely to give the green light to approve items related to firm innovation [47]. R\&D is a collaborative process that unfolds over time and require the support of top managers [48]. The innovation culture widely shared by top managers exerts an imperceptible influence on their behavior and induce them to provide convenience in improving the financial support and the living and working conditions of talents [10]. These kinds of actual support inspired by firm-proclaimed innovation culture are conducive to $R \& D$. Taken together, all arguments support the proposition that a firm-proclaimed innovation culture enhances the performance of firm innovation. Therefore, the following hypothesis is presented.

H1a. Firm proclaimed innovation culture is associated positively with firm innovation.

Employee-perceived innovation culture refers to the innovation culture shared widely by employees from different levels and departments. Firms that perform well in this respect may exhibit many features. First, a key feature, highlight autonomy, denotes a relatively high level of discretion granted to employees within a firm [49]. Innovation derived from inspiration and autonomy contributes to constructing a relaxed and free working environment that facilitates employees to create in it [50]. Moreover, autonomy is also conducive for employees to devote limited time and energy to solving the key problems in R\&D [51]. A second key feature is learning orientation, which indicates the degree to which firms are committed to learn, criticize, and reconstruct advanced technology and new knowledge [52]. In the process of innovation, employees should be adept in absorbing internal and external intangible resources represented by new knowledge, which could facilitate them to achieve more results with half the effort [53]. Notably, learning orientation also encourages employees to question the correctness of obtained information as well as the applicability of using them in the innovation process [30]. The third key factor is risk-taking, which expresses the degree to which firms are prepared to accept the risks derived from the high uncertainty of innovation [12]. It encourages firms to treat occasional setbacks as normal and invest sufficient resources in innovation, even if the likelihood of success is uncertain [54]. This feature also urges employees to pay more attention to breakthrough innovation without the worries behind it [55]. Taken together, innovation culture facilitates employees to learn and extend new knowledge autonomously and create new ideas, products or services further under risks and challenges. Thus, the following hypothesis is proposed.

H1b. Employee perceived innovation culture is positively associated with firm innovation.

\subsection{Moderating effect of $R \& D$ intensity}

Innovation culture and $R \& D$ investment interact to affect firm innovation [16]. As R\&D intensity increases, the expected outputs and standards of performance appraisal formulated by top managers are promoted correspondingly, which may curtail the employees' intrinsic motivation cultivated by innovation culture. We posit that $R \& D$ intensity 
moderates the effect of innovation culture on firm innovation.

Innovation relies heavily on employees' intrinsic motivation, which is related closely to high-quality learning and creativity [56]. The individual with high intrinsic motivation performs a specific task for the work itself [57]. Similarly, the group of employees with high intrinsic motivation displays collective belief and experience that the colleagues work for the interests and challenges, regardless of the external rewards [56]. Previous studies indicate that innovation culture highlights autonomy and facilitates employees to invoke internal interest towards work [10]. That is, working in an environment with high innovation culture cultivates the intrinsic motivation of employees.

Unfortunately, innovation is also a process that depends strongly on R\&D intensity, which is an investment formulated by top managers [58]. Considering innovation usually connects to long-term performance and with a high failure rate, when investing in high $R \& D$ intensity, top managers set high goals and strict standards of performance appraisal to spur employees [59]. High input is always accompanied by high requirements.
Particularly for public firms, top managers face widespread pressure from numerous stakeholders, and managers are expected to focus on investment that may create considerable short-term performance that would induce shareholders or potential investors to obtain substantial stock market returns $[4,5]$. Thus, with the increase of R\&D intensity, the symbiotic tangible rewards, threats, deadlines, and competitive pressure diminish the intrinsic motivation of employees [60].

Taken together, the nature of innovation culture (e.g., highlight autonomy) enhances the intrinsic motivation of employees and the control derived from the increases of R\&D intensity weakens it. Therefore, we posit that the positive effect caused by innovation culture diminishes with the increases in $\mathrm{R} \& \mathrm{D}$ intensity.

H2a. The positive effect of firm proclaimed innovation culture on firm innovation is negatively moderated by R\&D intensity such that the positive effect is lower when R\&D intensity is higher.

H2b. The positive effect of employee perceived innovation culture on firm innovation is negatively moderated by $R \& D$ intensity such that the positive effect is lower when R\&D intensity is higher.

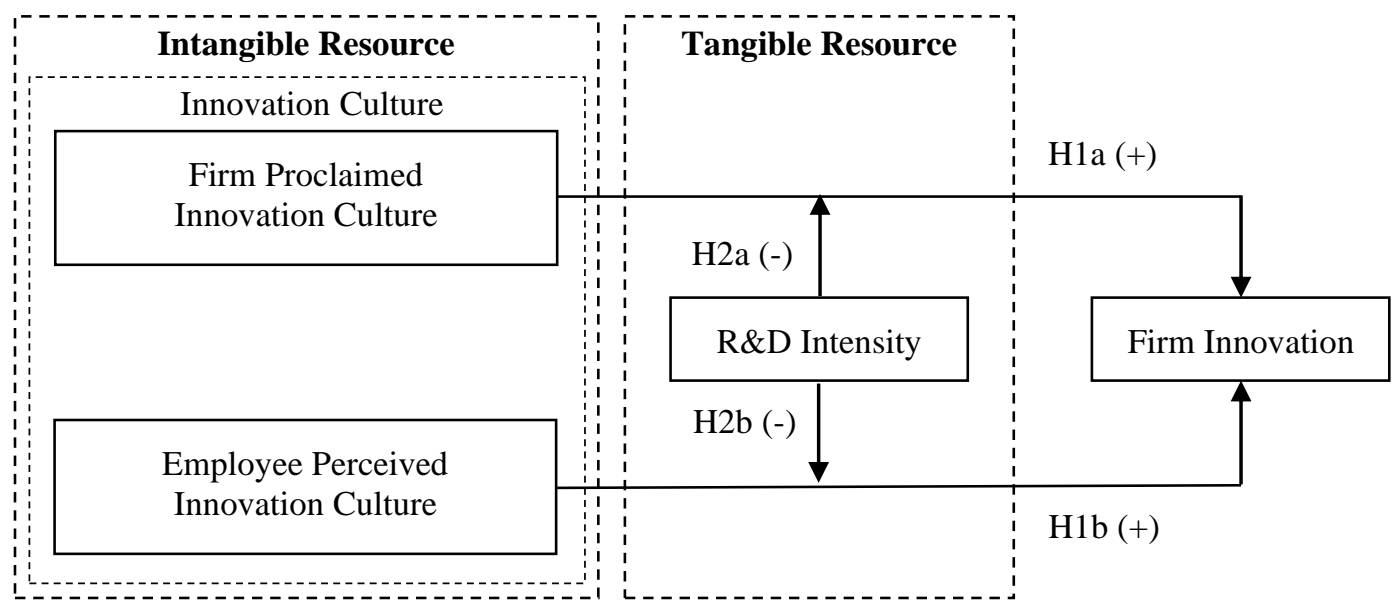

Figure 1. Research model

\section{Data and variable construction}

\subsection{Data acquisition and processing}

The sample examined in this research includes US public firms during the period of 2008-2016. Related data were collected from several sources. First, for employee-perceived innovation culture, we obtained employee-related data from Glassdoor, a leading career community in America. Second, following previous literature [9], we identified firmproclaimed innovation culture from each firm's official website that has one or more sections dedicated to describing firm's introduction, values, culture, mission, and vision. Third, for firm innovation, we obtained patent data from the U.S. Patent and Trademark Office. Fourth, we collected financial data from Compustat to calculate the control variables.

Notably, we use a novel method that combined text mining and deep learning to measure employee- 
perceived corporate culture and firm-proclaimed innovation culture. First, we obtain the original word list for measuring corporate culture (including innovation/create, collaborate, competition, and control) provided by Fiordelisi and Ricci [19]. Second, we enriched the word list based on word2vec, a deep learning tool derived from Google that provides excellent execution of the continuous bagof-words and skip-gram architectures for calculating vector representations of words [61]. In our research context, it takes the reviews provided by employees as input and produces the word vectors as output. The resulting word vector file can be used to extract the synonyms of the original bag of words, which would yield an extended word list. Third, based on the original and extended word lists, we use the word frequency multiplied by 100 to indicate each dimension of employee perceived corporate culture. A similar approach is also used to measure the firm proclaimed corporate culture, and consistent with previous literature, the value assigns to 1 if the word frequency is higher than 0 [9].

We sum up the data obtained before and ultimately form the "final dataset" for our empirical analysis. In our sample, 683 firm-year observations were provided by 274 firms in 14 industries. For each observation, an average of 203.77 employee reviews was covered and the full sample covers 191542 reviews in total.

\subsection{Research variables}

The dependent variable is firm innovation, which is measured by the total number of patents the firm filed (and eventually granted) in a year. Following previous literature [29, 62], because the process of innovation generally takes one year or more [43], we examine the effect of a firm's innovation culture on its patent applications one year ahead (for robustness, we obtain quantitatively and qualitatively similar results when choosing two or three years in advance).

The primary independent variables are the two dimensions of innovation culture. We identified firmproclaimed innovation culture from a public firm's official website that has one or more sections dedicated to describing their introduction, value, culture, mission, vision, etc. If these proclaimed items include the words highlight innovation, we code this variable to 1 and 0 otherwise. Nevertheless, the snapshot of the website was collected in 2017, thus similar to Guiso et al. we only choose the closest year (i.e., $t=2015$ ) in our sample to investigate the effect of firm-proclaimed innovation culture on firm innovation [9]. For employee-perceived innovation culture, we use the frequency of innovation-related words in employee reviews to indicate it. Furthermore, to investigate the moderating role of $\mathrm{R} \& \mathrm{D}$ intensity as stated in $\mathrm{H} 2 \mathrm{a}$ and $\mathrm{H} 2 \mathrm{~b}$, we add the indicator $R \& D \_$Intensity, which is defined as $\mathrm{R} \& \mathrm{D}$ expenditure divided by total sales to the model.

Following previous literature [16, 43, 63], we add a set of control variables (e.g., employee satisfaction, financial leverage, prior performance, firm size, firm age) to capture the confounding effects caused by firms and other dimensions of the corporate culture. All continuous variables are winsorized at bottom $1 \%$ and top $99 \%$ to account for potential outliers.

\section{Empirical analysis}

\subsection{Firm proclaimed innovation culture}

To test the relationship between firm proclaimed innovation culture and firm innovation (as shown in $\mathrm{H} 1 \mathrm{a}$ and $\mathrm{H} 2 \mathrm{a}$ ), we build the following model:

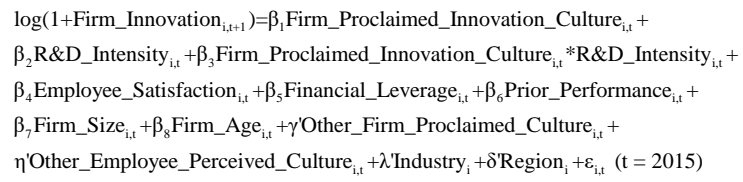

where $i$ denotes firm and $t$ denotes time. The dependent variable captures firm innovation: the natural logarithm of 1 plus the number of patents applied (and eventually granted) by firm $i$ in year $t+1$. The indicator of firm-proclaimed innovation culture is measured for firm $i$ over its fiscal year $t$. The model includes control variables that could affect firm innovation. Industry and Region capture the fixed effects of industry and region. We estimate the model by using the ordinary least squares (OLS) method and the result shown in Table 1.

Columns (1) and (2) indicate that the coefficient of firm-proclaimed innovation culture is insignificant, thereby suggesting that the effect between firmproclaimed innovation culture and firm innovation is insignificant. Thus, H1a is not supported. However, the coefficient of control variable employeeperceived innovation culture is significantly positive $(\mathrm{p}<0.05)$. Column $(2)$ of Table 1 reveals that the moderating effect of R\&D intensity is insignificant. Thus, H2a is also not supported. 
Table 1. Effects of firm proclaimed innovation culture on innovation

\begin{tabular}{|c|c|c|}
\hline & \multicolumn{2}{|c|}{ log(1+Firm_Innovation $t+1)$} \\
\hline & (1) & (2) \\
\hline Firm_Proclaimed_ & -0.056 & 0.014 \\
\hline Innovation_Culture & $(0.180)$ & $(0.247)$ \\
\hline R\&D_Intensity & $\begin{array}{c}5.015^{* * *} \\
(1.297)\end{array}$ & $\begin{array}{c}5.261^{* * *} \\
(1.522)\end{array}$ \\
\hline $\begin{array}{l}\text { Firm_Proclaimed_ } \\
\text { Innovation_Culture } \times\end{array}$ & & $\begin{array}{l}-0.706 \\
(1.767)\end{array}$ \\
\hline R\&D_Intensity & & \\
\hline Employee_Perceived_ & $0.340^{* *}$ & $0.341^{* * *}$ \\
\hline Innovation_Culture & $(0.167)$ & $(0.168)$ \\
\hline Employee_Satisfaction & $\begin{array}{l}-0.446^{*} \\
(0.269)\end{array}$ & $\begin{array}{l}-0.430 \\
(0.272)\end{array}$ \\
\hline Financial_Leverage & $\begin{array}{l}-1.017 \\
(0.647)\end{array}$ & $\begin{array}{l}-1.069 \\
(0.662)\end{array}$ \\
\hline Prior_Performance & $\begin{array}{c}1.881 \\
(1.163)\end{array}$ & $\begin{array}{c}1.847 \\
(1.174)\end{array}$ \\
\hline Firm_Size & $\begin{array}{l}0.698^{* * * *} \\
(0.105)\end{array}$ & $\begin{array}{l}0.698^{* * * *} \\
(0.105)\end{array}$ \\
\hline Firm_Age & $\begin{array}{c}0.002 \\
(0.003)\end{array}$ & $\begin{array}{c}0.001 \\
(0.003)\end{array}$ \\
\hline Constant & $\begin{array}{c}-5.361^{* * * *} \\
(1.700) \\
\end{array}$ & $\begin{array}{c}-5.359^{* * *} \\
(1.705) \\
\end{array}$ \\
\hline Other_Proclaimed_Culture & $\overline{\text { YES }}$ & YES \\
\hline Other_Perceived_Culture & YES & YES \\
\hline Industry FE & YES & YES \\
\hline Region FE & YES & YES \\
\hline Observations & 163 & 163 \\
\hline $\mathrm{R}^{2}$ & 0.464 & 0.465 \\
\hline Adjusted $\mathrm{R}^{2}$ & 0.357 & 0.353 \\
\hline F Statistic & $4.337^{* * *}$ & $4.159^{* * *}$ \\
\hline
\end{tabular}

\subsection{Employee perceived innovation culture}

Similarly, to test the relationship between employee perceived innovation culture and firm innovation (as shown in $\mathrm{H} 1 \mathrm{~b}$ and $\mathrm{H} 2 \mathrm{~b}$ ), we estimate the following model using OLS:

$\log \left(1+\right.$ Firm_Innovation $\left._{\mathrm{i}, t+1}\right)=\beta_{1}$ Employee_Perceived_Innovation_Culture $_{\mathrm{i}, \mathrm{t}}+$ $\beta_{2} R \& D$ Intensity $y_{i, t}+\beta_{3}$ Employee_Perceived_Innovation_Culture $_{i, t} * R \& D$ Intensity ${ }_{i, t}+$ $\beta_{4}$ Employee_Satisfaction $_{\mathrm{i}, \mathrm{t}}+\beta_{5}$ Financial_Leverage $_{\mathrm{i}, \mathrm{t}}+\beta_{6}$ Prior_Performance $_{\mathrm{i}, \mathrm{t}}+$ $\beta_{7}$ Firm_Size $_{\mathrm{i}, \mathrm{t}}+\beta_{8}$ Firm_Age $_{\mathrm{i}, \mathrm{t}}+\eta^{\prime}$ Other_Employee_Perceived_Culture ${ }_{\mathrm{i}, \mathrm{t}}+$ Region $_{\mathrm{i}}+$ $\lambda^{\prime}$ Industry $_{\mathrm{i}}+\delta^{\prime}$ Region $_{\mathrm{i}}+\varphi^{\prime}$ Year $_{\mathrm{t}}+\varepsilon_{\mathrm{i}, \mathrm{t}}(2008 \leq \mathrm{t} \leq 2015)$

Table 2 reports coefficient estimates for key variables. Column (1) shows the coefficient of employee-perceived innovation culture is significantly positive $(\mathrm{p}<0.01)$, thereby suggesting that employee-perceived innovation culture is positively related to firm innovation. Firms with high innovation-supportive culture shared by most employees tend to create high innovation output. Thus, H1b is supported.

Column (2) of Table 2 reveals the coefficient of the interaction term is significant at the 0.01 significance level. Given that the main effect of employee-perceived innovation culture is positive and that the interaction is negative, the positive effect of the employee-perceived innovation culture on firm innovation is small for firms with high $R \& D$ intensity provided other things are equal. Therefore, the effect of employee-perceived innovation culture on firm innovation is significantly moderated by $R \& D$ intensity and the positive effect is weak for firms with high R\&D intensity. Thus, H2b is supported.

Table 2. Effects of employee perceived innovation culture on innovation

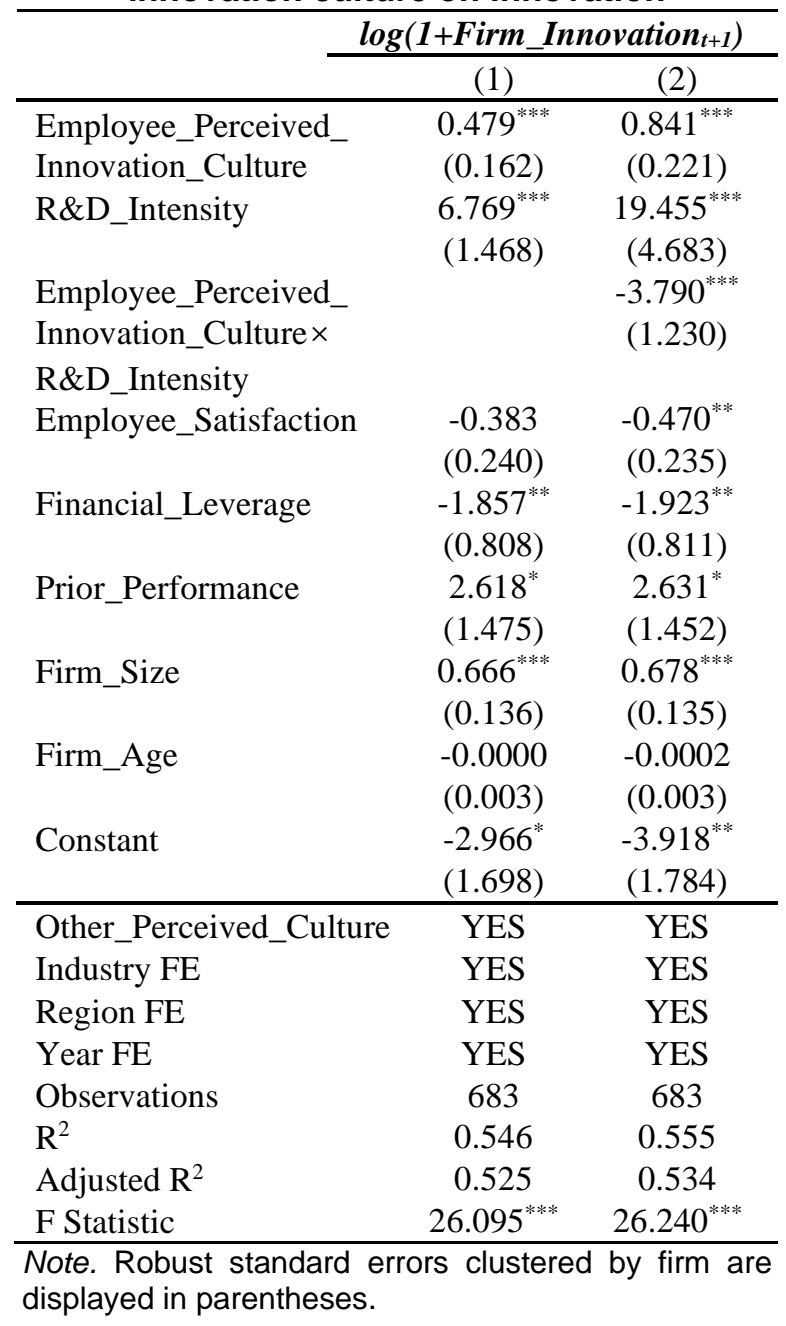




\section{Robustness check and extensions}

We conduct additional analyses, which are suppressed due to the limitations of space, to check further the robustness of our conclusions and to enrich our findings.

First, we identify the determinants of employeeperceived innovation culture and assess how firmrelated and employee-related factors affect it. Results suggest firms with a small size or perform well in work-life balance tend to have high employeeperceived innovation culture. Interestingly, the firms with higher senior management score (i.e., employees provide high rating to top managers) tend to have lower employee-perceived innovation culture. This finding is consistent with the view that innovation requires critical spirit and innovative talents who dare to criticize the behaviors and decisions of top management [64].

Second, we examine the effect of a firm's employee-perceived innovation culture on its patent applications two and three years ahead and obtain similar results.

Third, to explore the suitable cultural combination that facilitates innovation, we test how other kinds of cultures change the relationship between employeeperceived innovation culture and firm innovation. We identify a negative moderating effect caused by employee-perceived innovation culture.

\section{Concluding remark}

We quantify firm-proclaimed and employeeperceived innovation culture by using a combined method of deep learning and text mining and further document their effects on firm innovation. Moreover, we explore how R\&D intensity changes the influence caused by innovation culture. Our result suggests employee-perceived innovation culture positively influences innovation output but firm proclaimed innovation culture does not. Innovation culture proclaimed through official channels, which may exist in name only cannot cause significant influence on firm innovation. However, the innovation culture widely shared by employees from different levels and departments facilitate firms to gain innovation. More interestingly, in contradiction to the finding of a similar study, R\&D intensity negatively moderates the positive relationship between employee-perceived innovation culture and firm innovation, such that the effect of employee-perceived innovation culture is lower when R\&D intensity is higher. While innovation culture cultivates the intrinsic motivation of employees, symbiotic control causes the increase of R\&D intensity to weaken. We contribute to the current research by classifying innovation culture and using a text-mining method. We also provide novel knowledge by showing the different effectiveness of firm-claimed and employee-perceived culture, as well as the negative moderating role of $R \& D$ intensity.

\section{Acknowledgements}

This work was supported by the National Natural Science Foundation (NSFC) Programs of China [71722014 and 71771182], National Major Social Science Foundation Programs of China [16ZDA013] and the Youth Innovation Team of Shaanxi Universities "Big data and Business Intelligent Innovation Team".

\section{References}

[1] L. L. Berry, V. Shankar, J. T. Parish, S. Cadwallader, and T. Dotzel, "Creating new markets through service innovation," MIT Sloan Management Review, 2006, vol. 47 , no. 2 , pp. 56.

[2] S. Wies, and C. Moorman, "Going public: How stock market listing changes firm innovation behavior," Journal of Marketing Research, 2015, vol. 52, no. 5, pp. 694-709.

[3] V. A. Aggarwal, and D. H. Hsu, "Entrepreneurial exits and innovation," Management Science, 2013, vol. 60, no. 4, pp. 867-887.

[4] C. Moorman, S. Wies, N. Mizik, and F. J. Spencer, "Firm innovation and the ratchet effect among consumer packaged goods firms," Marketing Science, 2012, vol. 31, no. 6, pp. 934-951.

[5] N. Mizik, "The theory and practice of myopic management," Journal of Marketing Research, 2010, vol. 47, no. 4, pp. 594-611.

[6] S. Khazanchi, M. W. Lewis, and K. K. Boyer, "Innovation-supportive culture: The impact of organizational values on process innovation," Journal of Operations Management, 2007, vol. 25, no. 4, pp. 871-884. [7] G. J. Tellis, J. C. Prabhu, and R. K. Chandy, "Radical innovation across nations: The preeminence of corporate culture," Journal of Marketing, 2009, vol. 73, no. 1, pp. 323.

[8] E. H. Schein, Organizational Culture and Leadership, John Wiley \& Sons, New Jersey, 2010.

[9] L. Guiso, P. Sapienza, and L. Zingales, "The value of corporate culture," Journal of Financial Economics, vol. 117,2015 , no. 1 , pp. $60-76$.

[10] P. K. Ahmed, "Culture and climate for innovation," European Journal of Innovation Management, 1998, vol. 1, no. 1 , pp. 30-43.

[11] D. De Tienne, and P. Mallette, "Antecedents and outcomes of innovation-oriented cultures," International Journal of Business and Management, 2012 ,vol. 7, no. 18, pp. 1. 
[12] M. Terziovski, "Innovation practice and its performance implications in small and medium enterprises (SMEs) in the manufacturing sector: A resource-based view," Strategic Management Journal, 2010, vol. 31, no. 8, pp. 892-902.

[13] U. De Brentani, "Innovative versus incremental new business services: Different keys for achieving success," Journal of Product Innovation Management, 2001 vol. 18, no. 3, pp. $169-187$.

[14] E. J. Kleinschmidt, U. De Brentani, and S. Salomo, "Performance of global new product development programs: A resource-based view," Journal of Product Innovation Management, 2007, vol. 24, no. 5, pp. 419-441.

[15] R. M. Ryan, V. Mims, and R. Koestner, "Relation of reward contingency and interpersonal context to intrinsic motivation: A review and test using cognitive evaluation theory," Journal of Personality and Social Psychology, 1983, vol. 45, no. 4, pp. 736 .

[16] S. Wang, R. M. Guidice, J. W. Tansky, and Z. M. Wang, "When R\&D spending is not enough: The critical role of culture when you really want to innovate," Human Resource Management, 2010, vol. 49, no. 4, pp. 767-792.

[17] M. Y.-C. Chen, C. Y.-Y. Lin, H.-E. Lin, and E. F. McDonough, "Does transformational leadership facilitate technological innovation? The moderating roles of innovative culture and incentive compensation," Asia Pacific Journal of Management, 2012, vol. 29, no. 2, pp. 239-264.

[18] R. A. King, P. Racherla, and V. D. Bush, "What we know and don't know about online word-of-mouth: A review and synthesis of the literature," Journal of interactive marketing, 2014, vol. 28, no. 3, pp. 167-183.

[19] F. Fiordelisi, and O. Ricci, "Corporate culture and CEO turnover," Journal of Corporate Finance, 2014, vol. 28, pp. 66-82.

[20] C. M. Axtell, D. J. Holman, K. L. Unsworth, T. D. Wall, P. E. Waterson, and E. Harrington, "Shopfloor innovation: Facilitating the suggestion and implementation of ideas," Journal of Occupational and Organizational Psychology, 2000, vol. 73, no. 3, pp. 265-285.

[21] S. Liu, F. Xia, B. Gao, G. Jiang, and J. Zhang, "Hybrid influences of social subsystem and technical subsystem risks in the crowdsourcing marketplace," IEEE Transactions on Engineering Management, 2019.

[22] K. Urabe, J. Child, and T. Kagono, Innovation and Management: International Comparisons, Walter de Gruyter GmbH \& Co KG, Berlin, 2018.

[23] G. N. Chandler, C. Keller, and D. W. Lyon, "Unraveling the determinants and consequences of an innovation-supportive organizational culture," Entrepreneurship Theory and Practice, 2000, vol. 25, no. 1, pp. 59-76.

[24] M. Sadegh Sharifirad, and V. Ataei, "Organizational culture and innovation culture: Exploring the relationships between constructs," Leadership \& Organization Development Journal, 2012, vol. 33, no. 5, pp. 494-517. [25] R. M. Grant, "The resource-based theory of competitive advantage: Implications for strategy formulation," California Management Review, 1991, vol. 33, no. 3, pp. 114-135.
[26] H. Mao, S. Liu, J. Zhang, and Z. Deng, "Information technology resource, knowledge management capability, and competitive advantage: The moderating role of resource commitment," International Journal of Information Management, 2016, vol. 36, no. 6, pp. 10621074.

[27] H. Görg, and E. Strobl, "The effect of R\&D subsidies on private R\&D," Economica, 2007, vol. 74, no. 294, pp. 215-234.

[28] J. Guan, and R. C. Yam, "Effects of government financial incentives on firms' innovation performance in China: Evidences from Beijing in the 1990s," Research Policy, 2015, vol. 44, no. 1, pp. 273-282.

[29] J. Lerner, and J. Wulf, "Innovation and incentives: Evidence from corporate R\&D," The Review of Economics and Statistics, 2007, vol. 89, no. 4, pp. 634-644.

[30] M. Brettel, and N. J. Cleven, "Innovation culture, collaboration with external partners and NPD performance," Creativity and Innovation Management, 2011, vol. 20, no. 4, pp. 253-272.

[31] A. Abbey, and J. W. Dickson, "R\&D work climate and innovation in semiconductors," Academy of Management Journal, 1983, vol. 26, no. 2, pp. 362-368.

[32] G. Hofstede, B. Neuijen, D. D. Ohayv, and G. Sanders, "Measuring organizational cultures: A qualitative and quantitative study across twenty cases," Administrative science quarterly, 1990, pp. 286-316.

[33] Y. Berson, S. Oreg, and T. Dvir, "CEO values, organizational culture and firm outcomes," Journal of Organizational Behavior, 2008, vol. 29, no. 5, pp. 615-633. [34] S. Dorabjee, C. Lumley, and S. Cartwright, "Culture, innovation and successful development of new medicinesan exploratory study of the pharmaceutical industry," Leadership \& Organization Development Journal, 1998, vol. 19, no. 4, pp. 199-210.

[35] I. Nonaka, The knowledge-creating company, Harvard Business Review, 2007, vol. 85, no. 7/8, pp. 162-171.

[36] H. Liu, S. Wei, W. Ke, K. K. Wei, and Z. Hua, "The configuration between supply chain integration and information technology competency: A resource orchestration perspective," Journal of Operations Management, 2016, vol. 44, pp. 13-29.

[37] F. Chirico, D. G. Sirmon, S. Sciascia, and P. Mazzola, "Resource orchestration in family firms: Investigating how entrepreneurial orientation, generational involvement, and participative strategy affect performance," Strategic Entrepreneurship Journal, 2011, vol. 5, no. 4, pp. 307-326.

[38] C. A. Hartnell, A. J. Kinicki, L. S. Lambert, M. Fugate, and P. Doyle Corner, "Do similarities or differences between CEO leadership and organizational culture have a more positive effect on firm performance? A test of competing predictions," Journal of Applied Psychology, 2016, vol. 101, no. 6, pp. 846.

[39] F.-T. Mousa, and J. Chowdhury, "Organizational slack effects on innovation: The moderating roles of CEO tenure and compensation," Journal of Business Economics and Management, 2014, vol. 15, no. 2, pp. 369-383.

[40] J. Albors-Garrigos, and R. R. Barrera, "Impact of public funding on a firm's innovation performance: Analysis of internal and external moderating factors," 
International Journal of Innovation Management, 2011, vol. 15, no. 06, pp. 1297-1322.

[41] R. Parthasarthy, and J. Hammond, "Product innovation input and outcome: Moderating effects of the innovation process," Journal of Engineering and Technology Management, 2002, vol. 19, no. 1, pp. 75-91.

[42] J. Han, I. Bose, N. Hu, B. Qi, and G. Tian, "Does director interlock impact corporate R\&D investment?," Decision Support Systems, 2015, vol. 71, pp. 28-36.

[43] J. J. He, and X. Tian, "The dark side of analyst coverage: The case of innovation," Journal of Financial Economics, 2013, vol. 109, no. 3, pp. 856-878.

[44] M. Makri, and T. A. Scandura, "Exploring the effects of creative CEO leadership on innovation in hightechnology firms," The Leadership Quarterly, 2010, vol. 21, no. 1 , pp. $75-88$.

[45] Y. Chen, G. Tang, J. Jin, Q. Xie, and J. Li, "CEO s' Transformational Leadership and Product Innovation Performance: The Roles of Corporate Entrepreneurship and Technology Orientation," Journal of Product Innovation Management, 2014, vol. 31, pp. 2-17.

[46] M. D. Mumford, G. M. Scott, B. Gaddis, and J. M. Strange, "Leading creative people: Orchestrating expertise and relationships," The Leadership Quarterly, 2002, vol. 13, no. 6, pp. 705-750.

[47] M. S. Yadav, J. C. Prabhu, and R. K. Chandy, "Managing the future: CEO attention and innovation outcomes," Journal of Marketing, 2007, vol. 71, no. 4, pp. 84-101.

[48] A. M. Pettigrew, R. W. Woodman, and K. S. Cameron, "Studying organizational change and development: Challenges for future research," Academy of Management Journal, 2001, vol. 44, no. 4, pp. 697-713.

[49] J. P. De Jong, and D. N. Den Hartog, "How leaders influence employees' innovative behaviour," European Journal of Innovation Management, 2007, vol. 10, no. 1, pp. 41-64.

[50] C. P. Theurer, A. Tumasjan, and I. M. Welpe, "Contextual work design and employee innovative work behavior: When does autonomy matter?," PloS One, 2018, vol. 13, no. 10, pp. e0204089.

[51] S. Beugelsdijk, "Strategic human resource practices and product innovation," Organization Studies, 2008, vol. 29 , no. 6, pp. 821-847.

[52] Y. Gong, J.-C. Huang, and J.-L. Farh, "Employee learning orientation, transformational leadership, and employee creativity: The mediating role of employee creative self-efficacy," Academy of Management Journal, 2009, vol. 52, no. 4, pp. 765-778.

[53] J. Darroch, "Knowledge management, innovation and firm performance," Journal of Knowledge Management, 2005, vol. 9, no. 3, pp. 101-115.

[54] A. Herrmann, O. Gassmann, and U. Eisert, "An empirical study of the antecedents for radical product innovations and capabilities for transformation," Journal of Engineering and Technology Management, 2007, vol. 24, no. 1-2, pp. 92-120.

[55] J. Jamrog, M. Vickers, and D. Bear, "Building and sustaining a culture that supports innovation," People and Strategy, 2006, vol. 29, no. 3, pp. 9.
[56] T. Yidong, and L. Xinxin, "How ethical leadership influence employees' innovative work behavior: A perspective of intrinsic motivation," Journal of Business Ethics, 2013, vol. 116, no. 2, pp. 441-455.

[57] R. M. Ryan, and E. L. Deci, "Self-determination theory and the facilitation of intrinsic motivation, social development, and well-being," American Psychologist, 2000, vol. 55, no. 1, pp. 68.

[58] Q. Li, P. G. Maggitti, K. G. Smith, P. E. Tesluk, and R. Katila, "Top management attention to innovation: The role of search selection and intensity in new product introductions," Academy of Management Journal, 2013, vol. 56, no. 3, pp. 893-916.

[59] V. L. Barker III, and G. C. Mueller, "CEO characteristics and firm R\&D spending," Management Science, 2002, vol. 48, no. 6, pp. 782-801.

[60] R. M. Ryan, and E. L. Deci, "Intrinsic and extrinsic motivations: Classic definitions and new directions," Contemporary Educational Psychology, 2000, vol. 25, no. 1, pp. 54-67.

[61] T. Kenter, and M. De Rijke, "Short text similarity with word embeddings." Proceedings of the 24th ACM international on conference on information and knowledge management, 2015, pp. 1411-1420.

[62] T. J. Chemmanur, and X. Tian, "Do antitakeover provisions spur corporate innovation? A regression discontinuity analysis," Journal of Financial and Quantitative Analysis, 2018, pp. 1-32.

[63] J. Qi Dong, K. J. McCarthy, and W. W. Schoenmakers, "How central is too central? Organizing interorganizational collaboration networks for breakthrough innovation," Journal of Product Innovation Management, 2017, vol. 34, no. 4 , pp. 526-542.

[64] D. J. Teece, "Towards a capability theory of (innovating) firms: Implications for management and policy," Cambridge Journal of Economics, 2017, vol. 41, no. 3, pp. 693-720. 